\title{
МОРФОЛОГІЧНИЙ СКЛАД ТУШ ІМУНОКАСТРОВАНИХ ТА НЕКАСТРОВАНИХ СВИНОК 3 А РІЗНОЇ ПЕРЕДЗАБІЙНОЇ ЖИВОЇ МАСИ
}

\author{
Андрєєва Діана Миколаївна \\ аспірант спец. 204 «ТВППТ» \\ Миколаївський національний аграрний університет \\ ORCID ID: 0000-0003-4572-0856 \\ Email: andreevasvk@gmail.com
}

Повод Микола Григорович доктор сільськогосподарських наук, професор Сумський національний аграрний університет ORCID ID: 0000-0001-9272-9672/ W-1565-2018

Email: nic.pov@ukr.net

Вербельчук Тетяна Василівна кандидат сільськогосподарських наук, доцент Поліський національний університет ORCID: 0000-0001-7334-4507 Email: ver-ba555@ukr.net

Вербельчук Сергій Петрович кандидат сільськогосподарських наук, доцент Поліський національний університет ORCID: 0000-0002-1136-5617

Email: verba5551@ukr.net

В статті проведено порівняльну оцінку морфологічного складу туш та співвідношення окремих тканин в ній у імунокастрованих і некастрованих свинок за різної передзабійної живої маси отриманих від помісних свиноматок ірландського ландраса та ірландського йоркшира і кнурів синтетичної лінії МахGro. Найбільший вміст м'яса у масі туші 71,8\% мали некастровані свинки за передзабійної маси 110 ка, тоді як у інших піддослідних свинок цей показник становив 71,1\%. Найбільшу частку жиру у туші 19,2\%, мали імунокастровані свинки вагової категорії 130 ке, що на 0,2\% більше порівняно з некастрованими свинками такої ж вагової категорії. Найменшу частку жирової тканини виявлено у тушах некастрованих тварин за передзабійної маси 110 кг, що достовірно на 0,8\% менше ніж у їх імунокастрованих аналогів. За часткою кісток у тушах піддослідних тварин за обох вагових категорій помічено тенденцію незначного зменшення цього показника у імунокастрованих свинок. Так частка кісток у тушах некастрованих тварин за передзабійної живої маси 110 кг та 130 ке виявилась невірогідно більшою відповідно на 0,1\% та 0,2\% порівняно з їх імунокастрованими аналогами. Найкраще співвідношення м'яса до кісток мали імунокастровані тварини за передзабійнї живої маси 130 ке. Їх туші мали більше м'язової тканини ніж кісткової в 7,33 рази, що на 0,15 одиниць менше порівняно з їх некастрованими аналогами. У імунокастрованих та некастрованих свинок за вагової категорії 110 кг різниці за м'ясо-кістковим співвідношенням не виявлено. М'ясо-сальне співвідношення було кращим у некастрованих свинок за обох вагових категорій. Некастровані тварини за передзабійної маси 110 та 130 кг мали тенденцію до покращення цього співвідношення відповідно на 0,21 та на 0,04 одиниці порівняно з аналогами дослідної групи. Застосування імунної кастрації для свинок не несе в собі негативного впливу на морфологічний склад туш. Більшого впливу на морфоологічний склад як некастрованих так і імунокастрованих свинок мала їх передзабійна жива маса. 3 їі збільшенням знижувався вміст кісток та збільшувався вміст жиру, тоді як вміст м'язової тканини залишався практично стабільним.

Ключові слова: свинка, імунна кастрація, обвалювання, морфоологічний склад, кісткова тканина, м'язова тканина, жирова тканина, м'ясо-сальні якості свиней.

DOl: https://doi.org/10.32845/bsnau.Ivst.2021.4.8

Останніми десятиріччями в світі набуває популярності гуманне ставлення до тварин. Особливо це відчутно в країнах $€ С$ де законодавчо закріплені певні норми і обмеження при утриманні свиней. Одним із них є заборона кастрації свиней без анестезії. В зв'язку з чим вишукується можливості альтернативи хірургічній кастрації, одним з яких $є$ імунологічна кастрація. Цей спосіб достатньо широко використовують в світі для покращення якості м'яса самців. Останнім часом в наукових колах набуло широкого обговорення імунологічна кастрація свинок. Але вплив цієї кастра-

ції на продуктивність свинок та якість їх туш ще $є$ недостатньо вивченим, особливо в Україні.

Попри тривалий і постійний занепад свинарства в державі, можна відмітити, що виробництво свинини в Україні, хоча і не в повній мірі, а фррагментально і в поки-що на окремих свинокомплексах, але все ж поступово переходить в етап трансформування від низько-інтенсивної до високоінтенсивної галузі. Зокрема є зрушення у сфері модернізації старих і впровадженні нових сучасних технологій [5]. За їх використання важливими $є з$ позитивні зрушення в кожному 
3 технологічних процесів. Метод імунологічної кастрації дозволяє відгодовувати кнурів та свинок великими групами на спеціалізованих товарно-відгодівельних свинарських комплексах.

Пошук впровадження нових методик кастрації свинок викликає найбільший інтерес у виробників. Це пов'язано 3 відгуками споживачів свинини через специфічний кнурячий запах та смак у м'ясі та салі свинок. Однією з причин специфічного запаху є вміст андростенона (5a-androst-16-en-3one, C19H280), скатола (4-метил-2,3-бензпіррол, C9H9N) та індола (2,3-бензпіррол, С8H7N). Скатол - це метаболіт триптофана, котрий виробляється у процесі часткового розщеплення білків у товстому відділі кишечника. Головними складовими специфічного кнурячого запаху у м'ясі та салі свинок є група статевих стероїдних гормонів - кортикостероїди та гонадостероїди, які синтезуються ендокринними залозами. Джерелом їх синтезу є холестерин, а гормони є ліпідами, які проникають через клітинні мембрани, так як жиророзчинні, що забезпечує контроль усіх необхідних процесів на клітинному рівні. До групи стероїдних гормонів відносяться андрогени. Вони об'єднують статеві гормони кнурів та свинок, котрі синтезуються у статевих залозах яєчників нативних свинок. У нативних свинок тестостерон приймає участь у підтримці гормонального балансу статевих гормонів та репродуктивних фуннкцій. Продуктом розпаду тестостерона $€$ андростенон саме він у найбільшій мірі відповідає за прояв специфічного кнурячого запаху у нативних свинок [10, 18].

Імунологічна кастрація перешкоджає синтезу статевих гормонів, виробленю андростенона і скатола. Головний принцип імунокастрації свинок заснований на блокуванні сигналу гонадотропін-рилізинг фактору (GnRF) зменшуючи секрецію лютеїнізуючого гормону (LH) та фолікулостимулюючого гормону (FSH). Основна роль імунокастрації, це контроль гормонів репродуктивної функції у самок свиней. Дія імунокастрації досягається використанням природньої імунної системи самок свиней для досягнення ефекту кастрації. Гормональний препарат подібний вакцині «Improvac» містить синтетичний пептидний аналог гонадоліберин ковалентно кон'югований з імуногенним білком-носієм. Імунізуючий препарат «Improvac» - це білкова молекула, котра діє через імунну систему свиней, забезпечуючи тимчасовий ефект імунологічної кастрації свинок, виводячи речовини котрі викликають специфічний кнурячий запах. Препарат гормонально неактивний, але містить необхідні епітопи. Епітоп це антигенний детермінант, викликає імунну у біологічному організмі самок (sus scrofa) відповідь та взаємодіє з антитілами та ефекторними Т-лімфоцитами. 3 метою стимуляції ефективної відповіді антигонадотропін-рилізинг гормон антитіл та блокування стимуляції гіпоталамо-гіпофізарногонадної осі. Імунобіологічні властивості «Improvac» стимулюють імунну відповідь проти ендогенного гормону (GnRF), який контролює функцію яєчників та вироблення естрогену та тестостерону через гонадотропні гормони [3].

Мета-аналіз Batorek et al. [12] показав, що імунокастрати демонструють товстіший жир на спині, ніж цілі самці, що призводить до меншого відсотка нежирного м'яса в туші. 3 іншого боку, порівняння імунокастратів з хірургічними кастратами показує їх переваги щодо якості туші (нижча вгодованість туші, більш важка шинка та лопатка). Спосіб контролю відкладення жиру в імунокастратів - це маніпуляція з їх дієтою після другої вакцинації. Обмеження споживання корму [14] або енергетичне розведення [13] покращує м'якість туші завдяки меншому відкладенню жиру.

М'ясність свиней генетично зумовлена і успадковується на високому рівні. Встановлено, що цей показник залежить від генетичного потенціалу тварини і паратипових факторів, частка яких відповідно становить 63,7 і 36,3 \%. [2]. Прояв більшості господарсько-корисних ознак є результатом взаємодії генотипу з низкою факторів оточуючого середовища. Основними з яких є годівля, передзабійна жива маса,

мікроклімат приміщень, тип підлоги, щільність постановки тварин $[1,4,7,8,11,15,21,24]$. Вплив умов утримання на м'ясність свиней досягає близько $10 \%[1,11]$.

Результати мета-аналітики [12, 23] показують, що імунокастрати та хірургічні кастрати дуже схожі за ознаками якості м'яса. 3 іншого боку, у порівнянні з некастрованими самцями (в доповнення до уникнення проблеми специфічного запаху кнура), імунокастрати демонструють кращу якість м'яса, оскільки вони мають більше внутрішньом'язового жиру і ніжніше м'ясо. Їх жир також більш насичений, що вигідно $з$ технологічної точки зору. Крім того, на відміну від некастрованих самців, імунокастрати можуть бути забиті в більш старшому віці, завдяки чому їх м'ясо придатне для переробки на в'ялені м'ясні продукти, де потрібна сировина специфічної якості. Наявні дослідження, свідчать що м'ясо імунокастратів для виготовлення сухов'ялених продуктів, схоже 3 хірургічними кастратами за якістю м'яса та жиру (включаючи кількість та склад жирних кислот) і вважаються придатними для тривалого процесу дозрівання [16, 17, 22].

Згідно повідомлень вітчизняних авторів [6], морфологічний склад туш свиней найбільшою мірою залежить від передзабійної живої маси, далі від типу годівлі та термінів дорощування. За результатами проведених досліджень встановлено збільшення вмісту жиру та зменшення вмісту м'яса та кісток зі збільшенням передзабійної живої маси за обох типів годівлі незалежно від тривалості дорощування та не виявлено залежності цих показників від способу кастраціï.

Водночас, інші автори вказують, що морфологічний склад туш свиней залежав як від способу кастрації, так і від їх передзабійної живої маси. Туші кастрованих тварин мали більш товстий жир, виміряний у різних точках туші (від 0,1 до 3,6 мм над першим грудним хребцем і від 0,8 до 3,3 мм над 6-7 грудними хребцями) [20].

В доступній нам літературі не достатньо висвітлено вплив імунологічної кастрації на якість туш свинок, тому вивчення морфологічного складу туш імунокастрованих та некастрованих свинок є актуальним та своєчасним.

Мета дослідження полягала у вивченні впливу імунної кастрації та різної перездабійної живої маси свинок на морфологічний склад туш та співвідношення окремих тканин в ній.

Матеріали та методи досліджень. Для досягнення поставленої мети нами в грудні місяці 2020 року на базі Глобинського м'ясокомбінату було проведено дослідження морфологічного складу туш імунокастрованих та некастрованих свинок. Базою для закладки досліду було обрано цех відгодівлі №3 ТОВ «НВП «Глобинського свинокомплексу», де за методом груп аналогів було сфрормовано дві групи гібридних свинок отриманих від ірландського ландраса та ірландського йоркшира і кнурів синтетичної лінії MaxGro, по 
220 голів в кожній.

Свинок контрольної та дослідної груп поставили на відгодівлю у віці 70 діб, і на другий день після постановки індивідуально зважили та ідентифікували різнокольоровими бирками з індивідуальними номерами. Тваринам дослідної групи на 112 добу життя було введено вакцину Improvac фірми Зоетіс Україна, з розрахунку 2 мл на голову, та у віці 148 днів проведено ревакцинацію цією ж вакциною в такій же дозі. Відгодівля тварин обох груп здійснювалась за рідкого типу годівлі. Приготування корму та його роздавання відбувалась автоматизовано, однаковими порціями відповідно до кривої годівлі, за допомогою кормокухні австрійської фірми Veda. Bci ветеринарні та технологічні процедури були ідентичні для обох груп.

По завершенню 105-ти денної відгодівлі, всі піддослідні тварини були індивідуально зважені. Після чого з числа піддослідних тварин було відібрано по 10 голів імунокастрованих свинок з масою 110 та 130 кг. Аналогічні групи були сформовані із числа некастрованих піддослідних свинок. В кожній з груп свинкам було нанесено в ділянці заднього окосту тату з номером групи та індивідуальним номером тварини. Надалі сформовані групи тварин завантажили в окремі відсіки скотовозу i перевезено на Глобинський м'ясокомбінат, де після 12-ти годинної витримки тварини були повторно зважені та забиті відповідно до дСТУ 7158:2010.

Туші забитих тварин зважували і охолоджували впродовж 24-х годин при температурі від 2 до $-4^{\circ} \mathrm{C}$. Після охолодження проводили повторне зважування та обвалювання обох напівтуш за методикою [9] з подальшим визначенням маси в них м'язової, жирової та кісткової тканини. Далі проводились розрахунки щодо відсоткового вмісту перелічених вище тканин, та визначалося м'ясо-сальне та м'ясо-кісткове співвідношення.

Отримані результати досліду були обраховані біометрично за допомогою прикладних програм Microsoft Office Excel.

Результати досліджень. Відповідно до отриманих результатів морфологічного складу туш імунокастрованих та некастрованих свинок за різної передзабійної живої маси встановлено високі показники м'ясності піддослідних тварин. Так, частка м'язової тканини у масі туші імунокастрованих та некастрованих тварин за обох вагових категорій знаходилась в межах 71,1-71,8\%. Найбільший вміст м'яса у масі туші мали тварини контрольної групи за живої передзабійної маси 110 кг, та статистично вірогідно переважали на 0,70\% своїх імунологічно кастрованих аналогів.

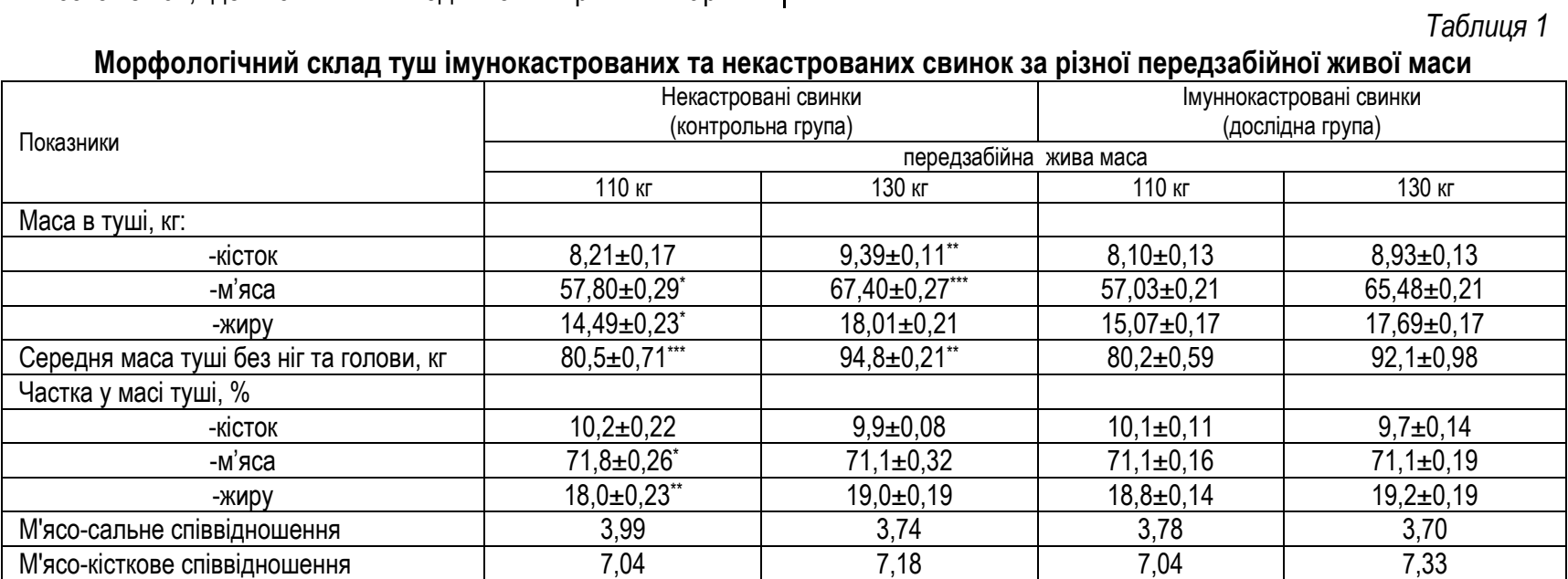

За часткою жиру у масі туші спостерігалася зворотна тенденція для всіх піддослідних тварин. Найбільшу частку жиру у туші мали імунокастровані свинки вагової категорії 130 кг, що склало 19,2\%, та виявилось на 0,2\% більше порівняно з некастрованими свинками такої ж вагової категорії. Найменшу частку жирової тканини виявлено у масі туші тварин контрольної групи з передзабійною масою 110 кг, що достовірно менше на 0,8\% ніж у їх імунокастрованих аналогів.

Порівнюючи співвідношення в тушах кісткової тканини у некастрованих та імунокастрованих свинок за обох вагових категорій помічено тенденцію незначного зменшення цього показника у тварин дослідної групи. Так частка кісток у тушах некастрованих тварин за передзабійної живої маси 110 та 130 кг виявилась не вірогідно більшою відповідно на 0,1\% та 0,2\% порівняно з їх аналогами за передзабійною живою масою імунокастрованими тваринами.

Проведений аналіз морфологічного складу туш імунокастрованих та некастрованих свинок за живої передзабійної маси 110 кг та 130 кг дав схожі результати за масою у туші м'язової тканини. Отже, тварини контрольної групи за вагової категорії 110 кг вірогідно перевищували тварин дослідної групи такої ж самої вагової категорії за масою м'яса у тушах на 0,77 кг або 1,33\%. За масою жиру у тушах на 2,03 кг або 4,00\% достовірно переважали своїх аналогів імунокастровані свинки живою передзабійною масою 110 кг. Різниця маси м'яса у тушах імунокастрованих та некастрованих свинок за живої маси 130 кг виявилася статистично достовірною, та становила 1,92 кг або 2,85\% на користь тварин контрольної групи. Маса жиру в тушах некастрованих свинок вагової категорії 130 кг мала тенденцію до збільшення на 1,18 кг або 1,78\% порівняно зі своїми імунокастрованими аналогами.

Маса кісток у тушах некастрованих свинок за живої передзабійної маси 110 кг статистично не вірогідно була вищою у імунокастрованих тварин такої самої вагової категорії на 0,11 кг або 1,34\%. Некастровані свинки вагової категорії 130 кг за масою кісток у тушах достовірно перевищували своїх імунокастрованих аналогів на 0,46 кг або 4,90\% .

Значної різниці за відсотковим співвідношенням маси 
кісток, м'яса та жиру до маси туші між некастрованими та імунокастрованими свинками ідентичних за передзабійною живою масою не виявлено. Проте все ж таки найкраще співвідношення м'яса до кісток спостерігалось у тварин дослідної групи з передзабійною живою масою 130 кг. Тварини цієї групи мали більше м'язової тканини ніж кісткової у 7,33 рази, що на 0,15 одиниць менше порівняно зі своїми некастрованими аналогами. У імунокастрованих та некастрованих свинок за вагової категорії 110 кг різниці за м'ясо-кістковим співвідношенням не виявлено.

В той час м'ясо-сальне співвідношення було краще у тварин контрольної групи за обох вагових категорій. Некастровані свинки за живої передзабійної маси 110 кг та 130 кг мали тенденцію до збільшення цього співвідношення відпо- відно на 0,21 та на 0,04 одиниці порівняно з імунокастрованми аналогами.

За результатами наших досліджень відносно того, що морфологічний склад туш свиней найбільшою мірою залежить від передзабійної живої маси співпадають з результатами вітчизняних авторів [6].

Висновки. Застосування імунної кастрації свинок не вплинуло на морфологічний склад туш.

Морфологічний склад як некастрованих так і імунокастрованих свинок залежав від їх передзабійної живої маси. 3 її збільшенням знижувався вміст кісток та збільшувався вміст жиру, тоді як вміст м'язової тканини залишався практично стабільним.

\section{Список використаної літератури:}

1. Волощук В. М. Теоретичне обґрунтування і створення конкурентоспроможних технологій виробництва свинини: моногр. Полтава, 2012. 348 с.

2. Гарт В. В., Гудилин И. И, Кочнев Н. И. Восприимчивость к стрессу свиней разных генотипов. Генетика, разведение и селекция свиней. 1988. С. 97-100.

3. ИМПРОВАК. URL: https://vicgroup.ru/catalog/p/preparaty-dlyaimmunologicheskoj-kastratcii/improvak/

4. Коваленко В. П. Внедрение нових технологий производства свинины. Свиноводство. 2000. № 6. С. 13-14.

5. Михалко О.Г. Сучасний стан та шляхи розвитку свинарства в світі та Україні. Вісник Сумського національного аграрного університету, серія «Тваринництво», 2021, Вип. $3(46), \quad$ С. http://repo.snau.edu.ua/bitstream/123456789/9537/1/6.pdf

6. Повод М.Г., Михалко О.Г., Вдовіченко Ю.В., Нечмілов В.М., Морфологічний склад туш свиней за різного типу годівлі, тривалості утримання на дорощувані та передзабійної живої маси. Збірник наукових праць міжнародної нуковопрактичної конференції «Аграрна наука та харчові технології», Вінницький НАУ , Вип. 3 (102). Вінниця, 2018, С. 47-56.

7. Селекція сільськогосподарських тварин / Ю. Ф. Мельник [та ін.]; за ред. Ю. Ф. Мельника. Київ: Інтас, 2008. С. 4954.

8. Старков А., Девин К., Пономарев Н. Влияние условий содержания на здоровье и продуктивность животных. Свиноводство. 2004. № 6. С. 30-33

9. Сучасні методики досліджень у свинарстві. Полтава, 2005. 228 с.

10. Эстрадиол. URL: https://helix.ru/kb/item/08-120

11. Bahelka, I. [et al.] 2007. The effect of sex and slaughter weight on intramuscular fat content and its relationship to carcass traits of pigs. Czech J. Animal Science. 52(5):122-129.

12. Batorek N, Čandek-Potokar M, Bonneau M, Van Milgen J. Meta-analysis of the elect of immunocastration on production performance, reproductive organs and boar taint com-pounds in pigs. Animal. 2012;6:1330-1338. DOI: 10.1017/S1751731112000146

13. Batorek N, Noblet J, Bonneau M, Čandek-Potokar M, Labussiere E. Efect of dietary net energy content on performance and lipid deposition in immunocastrated pigs. In: Book of Abstracts of the 64th Annual Meeting of the European Federation of Animal Science; 26-30 August 2013; Nantes, France. Wageningen: Wageningen Academic Publishers; 2013. p. 560

14. Batorek N, Škrlep M, Prunier A, Louveau I, Noblet J, Bonneau M, Čandek-Potokar M. Efect of feed restriction on hormones, performance, carcass traits, and meat quality in immunocastrated pigs. Journal of Animal Science. 2012;90:4593-4603. DOI: $10.2527 /$ jas $2012-5330$

15. Boyle L. A., Bjorklund L. Effects of fattening boars in mixed or single sex groups and split marketing on pig welfare // Anim. Welfare. 2007. Vol. 16. P. 259-262

16. Font-i-Furnols M, Gispert M, Soler J, Diaz M, Garcia-Regueiro JA, Diaz I, Pearce MC. Efect of vaccination against gonadotrophin-releasing factor on growth performance, carcass, meat and fat quality of male Duroc pigs for dry-cured ham production. Meat Science. 2012;91:148-154. DOI: 10.1016/j.meatsci.2012.01.008

17. Font-i-Furnols M, González J, Gispert M, Oliver MA, Hortós M, Pérez J, Guerrero L. Sensory characterization of meat from pigs vaccinated against gonadotropin releasing factor compared to meat from surgically castrated, entire male and female pigs. Meat Science. 2009;83:438-442. DOI: 10.1016/j.meatsci.2009.06.020

18. Levels of androstenone and skatole and the occurrence of boar taint in fat from young boars. URL: https://www.researchgate.net/publication/223892639_Levels_of_androstenone_and_s

katole_and_the_occurrence_of_boar_taint_in_fat_from_young_boars

19. Pinna A, Schivazappa C, Virgili R, Parolari G. Efect of vaccination against gonadotro-pin-releasing hormone $(\mathrm{GnRH})$ in heavy male pigs for Italian typical dry-cured ham production. Meat Science. 2015;110:153-169. DOI: doi.org/10.1016/j.meatsci.2015.07.002

20. Povod M., Kravchenko O., Getya A., Zhmailov V, Mykhalko O., Korzh O. And Kodak T., (2020). Influence of pre-killing living weight of the quality of carcass of hybrid pigs in the conditions of industrial pork production in Ukraine. Journal Scientific 
Papers Series Management, Economic Engineering in Agriculture and Rural Development, Vol. 20 (4), pp. 431-437.

21. Samarakone T. S., Gonyou H. W. Productivity and aggression at grouping of grower-finisher pigs in large groups. Canadian Journal animal Science. 2008. Vol. 88. No 1. P. 9-17.

22. Škrlep M, Čandek-Potokar M, Batorek Lukač N, Prevolnik Povše M, Pugliese C, Labussiere E, Flores M. Comparison of entire male and immunocastrated pigs for dry-cured ham production under two salting regimes. Meat Science. 2016;111:27-36. DOI: 10.1016/j.meatsci.2015.08.010

23. Trefan L, Doeschl-Wilson A, Rooke JA, Terlouw C, Bünger L. Meta-analysis of efects of gender in combination with carcass weight and breed on pork quality. Journal of Animal Science. 2013;91:1480-1492. DOI: 10.2527/jas.2012-5200

24. Whittemore C. Feeding for lean times. Pig Farming. 1982. Vol. 30. P. 53-55.

\section{References:}

1. Voloshchuk V. M. 2012. Theoretica iustificatio et creatio technologiae competitive ad productionem suillam [Theoretical substantiation and creation of competitive technologies of pork production]. Monographum, Poltava, $348 \mathrm{p}$.

2. Excitat V.V., Gudilin I.I., Kochnev N.I. 1988. Susceptibilitas ad accentus porcorum genotyporum diversorum [Susceptibility to stress of pigs of different genotypes]. Genetics, fetura et delectu porcorum. 97-100 pp.

3. IMPROVAC.URL:https://vicgroup.ru/catalog/p/preparaty-dlyaimmunologicheskoj-kastratcii/improvak/

4. Kovalenko V.P. 2000. Introductio novarum technologiarum productionis porcinae [Introduction of new technologies of pork production]. Porcus prolis. № 6. 13-14 pp.

5. Mikhalko O.G. 2021. Status et modi feturae sus in mundo et in Ucraina evolutionis current [Current state and ways of pig breeding development in the world and in Ukraine]. Bulletin of Sumy National Universitatis Agrariae, series "Livestock", Vol. 3 (46), pp. 61-78. http://repo.snau.edu.ua/bitstream/123456789/9537/1/6.pdf

6. Povod M.G., Mikhalko O.G., Vdovichenko Y.V., Nechmilov V.M. 2018. Compositio morphologica cadaverum porci pro diversis generibus pascendi, durationis educandi et praeeminentiae vivo pondere [Morphological composition of pig carcasses for different types of feeding, duration of rearing and pre-slaughter live weight]. Acta Internationalis Scientificae et practicae Conferentiae "Scientiae agriculturae et Technologiae Food", Vinnytsia NAU, Vol. 3 (102) , pp. 47-56.

7. Yu. F. Melnyk [etc.]. 2008. De fetura pecudum [Breeding of farm animals].Ad ed. Yu, F. Melnik. Kyiv: Intas,. P. 49-54

8. Starkov A., Devin K., Ponomarev N. 2004. Influentia habitationum conditionum in sanitate animalis et fructibus [Influence of housing conditions on animal health and productivity]. Porcus prolis. № 6. S. 30-33.

9. Modi investigationis modernae in fetura sus [Modern research methods in pig breeding]. 2005. Poltava, $228 \mathrm{p}$.

10. Estradiol. URL: https://helix.ru/kb/item/08-120

11. Bahelka I. [et al.] 2007. Effectus sexus et caedes ponderis in contentis intramuscularibus pinguibus et eius habitudine ad lineamenta cadaveris porcorum [The effect of sex and slaughter weight on intramuscular fat content and its relationship to carcass traits of pigs]. Bohemica J. Scientia Animalium. 52(5):122-129.

12. Batorek N., Candek-Potokar M., Bonneau M., Van Milgen J. 2012. Meta-analysis de effectu immunocastrationi de productione perficiendi, organis generationis et apri labem com-libris in porcos [Meta-analysis of the elect of immunocastration on production performance, reproductive organs and boar taint com-pounds in pigs]. Animal. № 6, 1330-1338 pp. DOI: 10.1017/S1751731112000146

13. Batorek N., Noblet J., Bonneau M., Candek-Potokar M., Labussiere E. 2013. Effectus de puritate rete energiae contentae in effectu et depositione lipidorum in porcos immunocastratos [Efect of dietary net energy content on performance and lipid deposition in immunocastrated pigs] . In: Book of Abstracts of the 64th Annual Meeting of the European Federation of Animal Science; 2630 August 2013; Nannetes, France. Wageningen: Wageningen Academici Editores; p. 560

14. Batorek N., Skrlep M., Prunier A., Louveau I., Noblet J., Bonneau M., Candek-Potokar M. 2012. Effectus pascendi restrictionis hormones, effectus, cadaveris lineamenta, et carnes qualitates in porcos immunos [Efect of feed restriction on hormones, performance, carcass traits, and meat quality in immunocastrated pigs. Journal of Animal Science]. Acta Scientiae Animalis. MMXII; 90, 4593-4603. DOI: $10.2527 / \mathrm{jas} 2012-5330$

15. Boyle L.A., Bjorklund L. 2007. Effectus saginationis apri in mixtis vel singulis sex gregibus et scissura venalicium in porco bono anim [Effects of fattening boars in mixed or single sex groups and split marketing on pig welfare]. Reipub. Vol. 16. P. 259-262 .

16. Font-i-Furnols M., Gispert M., Soler J., Diaz M., Garcia-Regueiro J.A., Diaz I., Pearce M.C. 2012. Effectus vaccinationis contra factorem gonadotrophin-relationis augmenti perficiendi, cadaver, carnes et pingues qualitates porcorum masculi Duroc pro productione pernae aridae curatae [Efect of vaccination against gonadotrophin-releasing factor on growth performance, carcass, meat and fat quality of male Duroc pigs for dry-cured ham production]. Caro Scientia. №91, pp. 148-154. DOI: 10.1016/j.meatsci.2012.01.008

17. Font-i-Furnols M., González J., Gispert M., Oliver M.A., Hortós M., Pérez J., Guerrero L. 2009. Sensorium carnis e porcorum vaccinatum contra gonadotropinum solvens factor comparatus ad carnem e surgice castratis, porcis integris masculis et feminae [Sensory characterization of meat from pigs vaccinated against gonadotropin releasing factor compared to meat from surgically castrated, entire male and female pigs]. Caro Scientia. №83, pp. 438-442. DOI: 10.1016/j.meatsci.2009.06.020

18. Campester of androstenone et skatole et eventum apri labem in pinguedine apri [Levels of androstenone and skatole and the occurrence of boar taint in fat from young boars]. URL:https://www.researchgate.net/publication/223892639_Levels_of_androstenone_et_s katole_et_occurrence_de_boar_taint_in_fat_from_young_boars

19. Pinna A., Schivazappa C., Virgili R., Parolari G. 2015. Effectus vaccinationis contra gonadotro-pin-hormonum solvens $(\mathrm{GnRH})$ in gravibus porcorum masculinorum ad productionem pernam typicam italicam aridam-curatam [Efect of vaccination against 
gonadotro-pin-releasing hormone $(\mathrm{GnRH})$ in heavy male pigs for Italian typical dry-cured ham production. Meat Science]. Caro Scientia. №110 pp. 153-169. DOI: doi.org/10.1016/j.meatsci.2015.07.002

20. Povod M., Kravchenko O., Getya A., Zhmailov V., Mykhalko O., Korzh O., Kodak T. 2020. Influentia pre-occidere vivum pondus qualitatis porcorum cadaveris hybridis in condicionibus productionis porcinae industrialis in Ucraina [Influence of pre-killing living weight of the quality of carcass of hybrid pigs in the conditions of industrial pork production in Ukraine]. Journal Scientific Papers Series Management, Economic Engineering in Agriculture and Rural Development, Vol. 20 (4), pp. 431-437.

21. Samarakone T. S., Gonyou H. W. 2008. Uber et aggressio porcorum finitororum in coetibus magnis [Productivity and aggression at grouping of grower-finisher pigs in large groups]. Acta Scientiarum Animalium Canadensium. Vol. 88. No 1. P. 9-17.

22. Škrlep M., Candek-Potokar M., Batorek Lukač N., Prevolnik Povše M., Pugliese C., Labussiere E., Flores M. 2016. Comparatio porcorum integritatum et immunostratorum pro siccis curatis pernae productionis sub duobus regiminibus salientibus [Comparison of entire male and immunocastrated pigs for dry-cured ham production under two salting regimes]. Caro Scientia. Vol 111, pp. 27-36. DOI: 10.1016/j.meatsci.2015.08.010

23. Trefan L., Doschl-Wilson A., Rooke J.A., Terlouw C., Bünger L. 2013. Meta-analysis effectuum generis in compositione cum pondere cadaveris et generis suilla qualitate [Meta-analysis of efects of gender in combination with carcass weight and breed on pork quality]. Acta Scientiae Animalis. Vol 91, pp.1480-1492. DOI: 10.2527/jas.2012-5200

24. Whittemore C. 1982.Pascendi tempora inniti [Feeding for lean times]. Porcus Rusticus. Vol. 30. P. 53-55.

Andrieieva Diana Mykolaivna, graduate student, Mykolayiv National Agrarian University

Povod Mykola Hryhorovych, Doctor of Agricultural Sciences, Professor, Sumy National Agrarian University

Verbelchuk Tetiana Vasylivna, Candidate of Agricultural Sciences, Associate Professor, Polissya National University

Verbelchuk Serhii Petrovych, Candidate of Agricultural Sciences, Associate Professor, Polissya National University

Morphological composition of carcases of immuno casted and uncastrated pigs at different pre-slaughter mass

The article describes a comparative assessment of the morphological composition of carcasses and the ratio of individual tissues in immunocastrated and uncastrated pigs at different pre-slaughter weight based on the results of previous scientific research. Pigs for the experiment were obtained from crossing local sows of Irish Landrace and Irish Yorkshire and boars of the MaxGro synthetic line. The study found the highest meat content in the carcass weight of $71,8 \%$ had uncastrated pigs at a preslaughter weight of $110 \mathrm{~kg}$. Other experimental pigs had this figure was $71,1 \%$. Immunocastrated pigs weighing $130 \mathrm{~kg}$ had the largest share of fat in the carcass of $19,2 \%$, which is $0,2 \%$ more than uncastrated pigs of the same weight category. The smallest share of adipose tissue was found in the carcasses of uncastrated animals with a pre-slaughter weight of $110 \mathrm{~kg}$, which is significantly $0,8 \%$ less than their immunocastrated counterparts. The proportion of bones in the carcasses of experimental animals in both weight categories showed a tendency to slightly reduce this figure in immunocastrated pigs. Thus, the proportion of bones in the carcasses of uncastrated animals at pre-slaughter weight of $110 \mathrm{~kg}$ and $130 \mathrm{~kg}$ was statistically incredibly higher by $0,1 \%$ and $0,2 \%$, respectively, compared to their immunocastrated counterparts. Immunocastrated animals with the best pre-slaughter weight of $130 \mathrm{~kg}$ had the best ratio of meat to bones. Their carcasses had 7,33 times more muscle tissue than bone, which is 0,ht category of $110 \mathrm{~kg}$, no difference in meat-bone ratio was found. The meat-fat ratio was better in uncastrated pigs in both weight categories. Uncastrated animals at pre-slaughter weight of 110 and $130 \mathrm{~kg}$ tended to improve this ratio by 0,21 and 0,04 units, respectively, compared with the analogues of the experimental group. The use of immune castration for pigs does not have a negative effect on the morphological composition of carcasses. Their pre-slaughter weight had a greater influence on the morphological composition of both uncastrated and immunocastrated pigs. As it increased, bone content decreased and fat content increased, while muscle content remained virtually stable.

Key words: mumps, immune castration, deboning, morphological composition, bone tissue, muscle tissue, adipose tissue, meat and fat qualities of pigs.

Дата надходження до редакції: 06.12.2021 р. 